\title{
Unraveling the Possible Routes of SARS-COV-2 Invasion into the Central Nervous System
}

Maria Lima, $M D^{1}$

Vasileios Siokas, MD, PhD ${ }^{1}$

Athina-Maria Aloizou, MD ${ }^{1}$

Ioannis Liampas, MD, MSC ${ }^{1}$

Alexios-Fotios A. Mentis, MD, PhD, PMC, $M P H^{1,2}$

Zisis Tsouris, MD, MSC ${ }^{1}$

Anastasios Papadimitriou, $M D^{1}$

Panayiotis D. Mitsias, MD, PhD ${ }^{3,4,5}$

Aristidis Tsatsakis, $P h D, D S c^{6}$

Dimitrios P. Bogdanos, MBA, MD, $P h D^{7}$

Stavros J. Baloyannis, MD, $P h D^{8}$

Efthimios Dardiotis, MD, PhD ${ }^{1, *} \oplus$

\author{
Address \\ *,1Department of Neurology, Laboratory of Neurogenetics, University of Thessaly, \\ University Hospital of Larissa, Larissa, Greece \\ Email:edar@med.uth.gr \\ ${ }^{2}$ Public Health Laboratories, Hellenic Pasteur Institute, Athens, Greece \\ ${ }^{3}$ Department of Neurology, School of Medicine, University of Crete, 71003, Her- \\ aklion, Greece \\ ${ }^{4}$ Department of Neurology, Henry Ford Hospital, Detroit, MI, 48202, USA \\ ${ }^{5}$ School of Medicine, Wayne State University, Detroit, MI, 48202, USA \\ ${ }^{6}$ Laboratory of Toxicology, School of Medicine, University of Crete, 71003, Her- \\ aklion, Greece \\ ${ }^{7}$ Department of Rheumatology and clinical Immunology, University General Hos- \\ pital of Larissa, Faculty of Medicine, School of Health Sciences, University of \\ Thessaly, Larissa, Greece \\ ${ }^{8}$ Research Institute for Alzheimer's Disease, Aristotelian University of Thessalo- \\ niki, Thessaloniki, Greece \\ Published online: 25 September 2020 \\ (C) Springer Science+Business Media, LLC, part of Springer Nature 2020
}


Keywords SARS-CoV-2 - SARS-2 - COVID-19 • Pandemic · Neuroinvasion · CNS penetration · Neurological manifestations $\cdot$ Coronaviruses $(\mathrm{CoVs}) \cdot$ Neurotropism $\cdot$ Neurovirulence

\begin{abstract}
Purpose of Review To describe the possible neuroinvasion pathways of Severe Acute Respiratory Syndrome-related Coronavirus-2 (SARS-CoV-2), the virus responsible for the Coronavirus disease-19 (Covid-19) pandemic.

Recent Findings We present data regarding the family of Coronaviruses (CoVs) and the central nervous system (CNS), and describe parallels between SARS-CoV-2 and other members of the family, which have been investigated in more depth and combine these findings with the recent advancements regarding SARS-CoV-2.

Summary SARS-CoV-2 like other CoVs is neuroinvasive, neurotropic and neurovirulent. Two main pathways of CNS penetration seem to be the strongest candidates, the hematogenous and the neuronal. The olfactory route in particular appears to play a significant role in neuroinvasion of coronaviruses and SARS-CoV-2, as well. However, existing data suggest that other routes, involving the nasal epithelium in general, lymphatic tissue and the CSF may also play roles in SARS-CoV-2 invasion into the CNS.
\end{abstract}

\title{
Introduction
}

Coronaviruses (CoVs) are a large family of viruses, capable of infecting many species of birds and mammals [1-3]. There are seven coronaviruses known to infect humans, called human coronaviruses (HCoVs) [4-6]. Clinically, infection with a coronavirus can be either asymptomatic or present with respiratory, gastrointestinal (GI), and neurological symptoms [7]. Four HCoVs, namely 229E, OC43, HKU1, NL63, are not considered to be very pathogenic $[8,9]$, while the rest, Severe Acute
Respiratory Syndrome-related Coronavirus (SARS-CoV) and Middle East Respiratory Syndrome-related Coronavirus (MERS-CoV) have caused two epidemics so far [8, $10-12]$, and the novel SARS-CoV-2 caused the current pandemic [13-16]; all these viral strands can lead to acute respiratory failure.

In this review, we aim to shed some light into how this novel virus can impact the central nervous system (CNS) by describing the routes of its invasion into the CNS.

\section{Presence of coronaviruses in the CNS}

Many studies have shown that coronaviruses are neuroinvasive, neurotropic, and neurovirulent in animals and humans [17-22]. In animals, the mouse hepatitis virus (MHV), a member of the coronavirus family, can infect microglia and astrocytes [23], as well as Koppler cells at choroid plexuses; a systemic model of infection with SARS-CoV showed that the virus reached the brain [24]. It has also been reported that human coronaviruses have the ability to infect primary cultures of human neural cells, fetal and adult astrocytes, adult microglia and adult oligodendrocytes [25-27]. [Fig. 1].

The detection of HCoVs in human CNS samples was described in the early 1980s, in autopsy tissues of patients with Multiple Sclerosis (MS) [28]. RNA from endemic prototype HCoV strains OC43 and 229E has also been detected in human brain samples [19], and can persist over time [29]. Neurological manifestations have also been described in the symptom constellation of the 


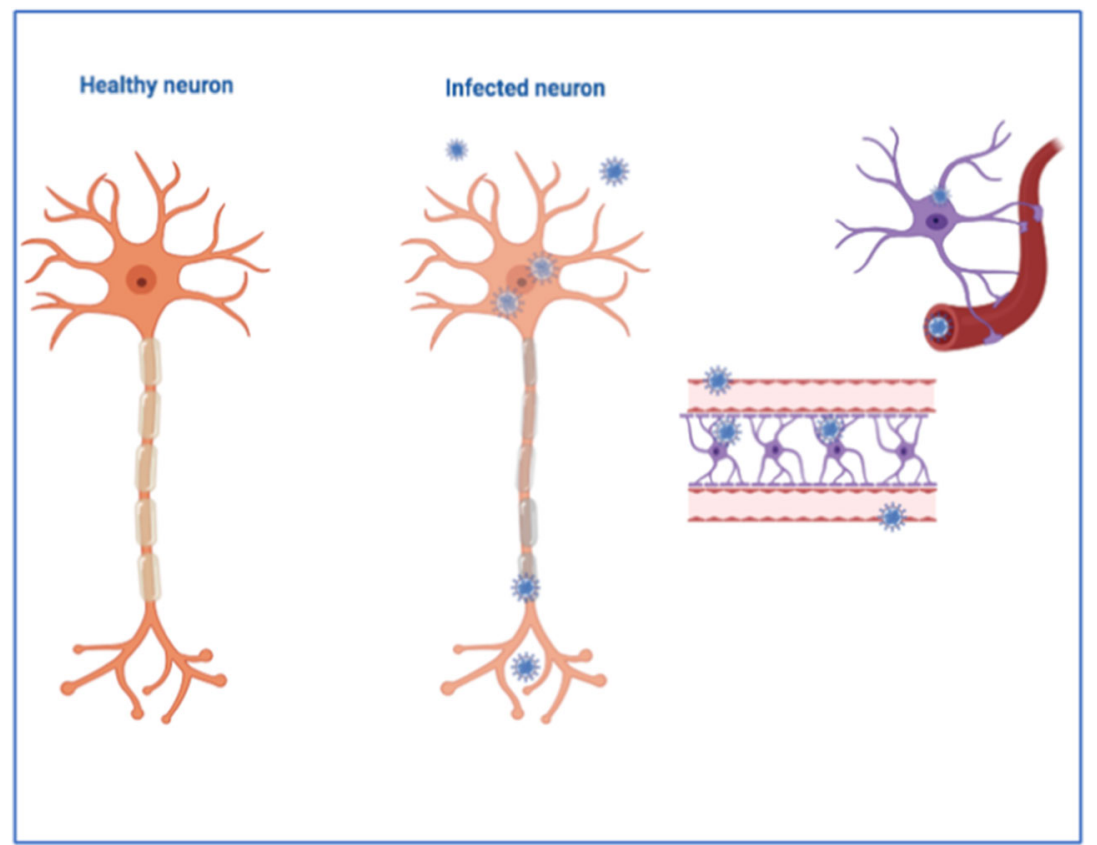

Fig. 1. A normal neuron and a neuron and astrocytes as infected with coronavirus.

two previous epidemics of MERS- [30, 31] and SARS-CoV [32], where the virus was also detected in cerebrospinal fluid (CSF) $[21,32,33]$. More specifically, it was shown that SARS-CoV could induce cerebral edema and meningeal vasodilation [34], neuronal morphological changes in the cortex and hypothalamus [35], neuronal ischemic lesions and necrosis, glial hyperplasia [36] and demyelination, while its genome sequences (viral particles) have also been detected in brain samples of infected patients [34-41].

Consequently, it comes as no surprise that a SARS-CoV-2 infection may present with neurological manifestations and CNS symptoms at high rates [42, 43], such as headache, confusion [44] and sensory disturbances, namely anosmia and ageusia [42•]. Additionally, entities such as encephalitis [45], acute cerebrovascular diseases [42, 46], acute necrotizing encephalopathy (ANE) [47], as well as demyelination and neuropathy [22] have also been reported in the current pandemic. Furthermore, the presence of SARS-CoV-2 has been established in the CSF of patients with acute neurologic symptoms, like seizures [48, 49] or encephalitis [45], at times combined with MRI findings pertaining to the condition at hand [48•]. Post-mortem examination of SARS-CoV-2-infected patients revealed the presence of SARS-CoV-2 in endothelial cells and pericytes of brain capillaries $[50 \bullet$ and neurons $[50,51]$, further confirming the presence of SARS-CoV-2 in the CNS. It has also been postulated that the presence of the virus in areas of the medulla, and the cardiorespiratory center in particular, may be one of the likely causes of COVID-19's respiratory failure [22, 52].

\section{Routes of neuroinvasion}

It was quickly established that SARS-CoV-2 binds to the receptor of the Angiotensin Converting Enzyme 2 (ACE2) with higher affinity than the other HCoVs, due to 
some structural differences in its "Receptor Binding Domain" of the S spike protein (S) $[15,53,54]$. Receptors of ACE2 exist in almost all human organs [55, 56], as well as in endothelial cells [52] and the CNS [55] [Fig. 2]. As such, it is highly likely that SARS-CoV-2, similarly to SARS-CoV $[57,58]$, makes use of these receptors in order to penetrate these tissues and trigger the perpetuation of immune responses [59] or finally invade the CNS, via the different pathways that we describe below.

\section{The HEMATOGENOUS pathway}

\section{Viremia}

Viremia follows the primary infection, and is the phase when most neurotropic viruses are present into the bloodstream, where they possibly stay for a period of time, before they finally reach the CNS [60]. Although HCoVs seem to mainly infect the respiratory tract and be self-restricting, they can potentially disrupt the epithelium barrier and invade the bloodstream [18]. Type II alveolar epithelial cells, which highly express ACE2, are the cells mainly infected by SARS-CoVs [39], thus allowing entrance of the virus to the blood circulation. Another possible pathway to the blood circulation could be through the epithelial cells of the GI tract [59], which also express ACE2 receptors and can be infected by SARS-CoV-2 [61-63]. While other pathways cannot be excluded, passage through the respiratory tract is the most plausible scenario.

\section{Penetration through the Blood-brain- barrier}

Once in the blood circulation, SARS-CoV-2 could bind to the ACE2 receptors of the endothelium $[50,52,55]$ and disrupt the Blood Brain Barrier (BBB), inducing edema, intracranial hypertension and/or penetration of the virus in the CNS [64, 65]. Neuroinvasion has been described for other coronaviruses in the past [29, 66]. In greater detail, Cabirac et al. (1993) showed that intravenous (IV) inoculation with MHV in owl monkeys led to brain and spinal cord infection, with the presence of viral RNA and/or antigen in the brain sites of inflammation, the blood vessels, and the endothelium [67]. Additionally, MERS-CoV can access the bloodstream, subsequently infecting endothelial cells in vivo [68]. Finally, PanizMondolfi et al., (2020) observed viral-like particles of SARS-CoV-2 in the endothelial cells and pericytes of brain capillaries as well as astrocytic processes, which actively overrode the BBB [50•], strongly supporting a hematogenousendothelial neuroinvasion-based hypothesis for SARS-CoV-2.

In a similar way, it can be postulated that SARS-CoV-2 could also infect the endothelial cells of the blood-cerebrospinal fluid barrier (BCSFB), and then spread into the CNS. Moreover, the choroid plexus and the circumventricular cerebral organs are not protected by the $\mathrm{BBB}$, and could thus be gates for the penetration of a virus into the CNS [69].

SARS-CoV-2 could also enter the CNS under conditions promoting an increase of the permeability of the $\mathrm{BBB}$, as a result of the release of inflammatory mediators (chemokines, cytokines) [70], and even a cytokine storm, following inflammation or hypoxemia induced by the respiratory distress syndrome, or even psychological stress [59, 71-73]. This paracellular transmigration pathway is mainly mediated by the destabilization or disruption of the tight junctions of the BBB [69]. 


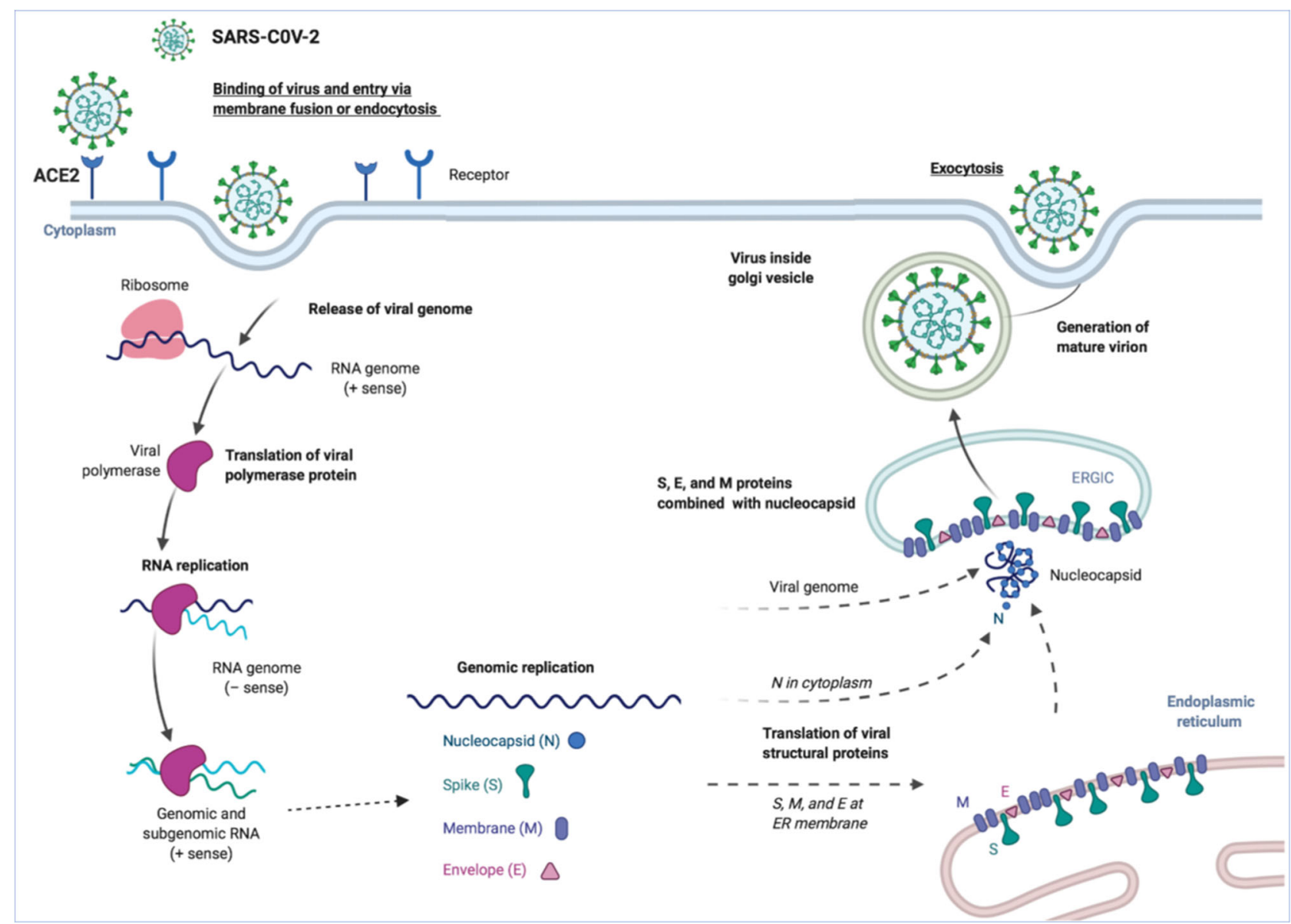

Figure 2. Entry of the virus into the host CNS-related cell and further spread. The single-stranded RNA (ssRNA) genome of Severe Acute Respiratory Syndrome-related Coronavirus-2 (SARS-CoV-2) encodes large polyproteins, which are proteolytically cleaved into 16 non-structural proteins (nsps). In addition, 9-12 ORFs are encoded through the transcription of a nested set of subgenomic RNAs. The virus forms spherical particles consisting of four structural proteins: the envelope glycoprotein spike (S), the envelope (E) and membrane $(\mathrm{M})$ transmembrane glycoproteins incorporated in the virion, and the protein nucleocapsid (N). The surface protein of the virus binds to its receptors, such as ACE 2. Following the entry of the virus into the host cell (such as the neuron), and the release of the viral genome, the viral RNA is uncoated in the cytoplasm. Translation of the viral polymerase protein is followed by RNA replication and subgenomic transcription; 0RF1a and ORF1ab are translated to create pp1a and pp1ab, which are cleaved by the proteases that are encoded by ORF1a to produce 16 nsps that form the RNA replicase-transcriptase complex. During the phase of replication, full-length (-)RNA copies of the genome are shaped and form templates for full-length (+)RNA genomes. Subgenomic (-)RNAs are transcribed into subgenomic (+)mRNAs. The step of translation is followed by the assembling of the resulting structural proteins into the nucleocapsid and viral envelope at the ER-Golgi intermediate compartment (ERGIC), followed by release of the nascent virion from the infected neuron cell. Created with a modified Biorender template (under license) as per de Wit et al. Nature Reviews Microbiology volume 14, pages523-534(2016).

\section{Peripheral immune cell transmigration - the "trojan horse" mechanism}

SARS-CoV-2 could also infect bloodstream leukocytes (mainly monocytes/ macrophages) [65] and myeloid cells, which become a viral pool for the diffusion of the virus towards the CNS $[69,74,75]$. SARS-CoV can infect lymphocytes and monocytes near the vessel wall $[34,35,38]$ and seems to use 
this "Trojan Horse" mechanism [18, 76]. Other coronaviruses present similar abilities; MHV can infect macrophages [23], while HCoV-OC43 and HCoV$229 \mathrm{E}$ can infect human monocytes/macrophages [76, 77]. In addition, $\mathrm{HCoV}$ $229 \mathrm{E}$ was able to infect murine and human dendritic cells in vitro [78], which express the human aminopeptidase $\mathrm{N}$ (CD13) leading to their subsequent activation [79]. SARS-CoV is also speculated to have as a binding receptor, the human CD13 [80]. It has been shown to infect immune cells, monocytes, macrophages and $\mathrm{T}$ lymphocytes in particular, which are consistently reduced in these patients (lymphopenia), even at early disease stages [35], something that has been reported for SARS-CoV-2 patients as well [42•]. Thus, we can hypothesize that SARS-CoV-2 uses immune circulating cells [42•] and dendritic cells to disseminate into other tissues and the CNS. It is possible that monocytes/macrophages could also be a "future" source of SARS-CoV-2, as is the case of other HCoVs [19], since the infection of these leukocytic cell lines can persist over time [76].

\section{The olfactory pathway}

The olfactory pathway is an excellent neuronal pathway for neuroinvasive respiratory viruses [81] that access the body intranasally [64], as the olfactory nerve communicates both with the nasal epithelium and the olfactory bulb [64, 69]. This pathway seems to be one possible mechanism of neuroinvasion for coronaviruses, including SARS-CoV-2 [39, 90, 91].

In animal models, intranasal inhalation of CoVs can lead to cerebral infection. For example, MHV induced infection in mice, and its RNA was detected in brain and muscles [92]. HCoV-OC43 also invades the CNS via the could be the neuronal pathway. Some viruses can invade from the nerve "ending", i.e. the peripheral nerves [64, 81]. However, some viruses can invade from the nerve "ending", i.e. the peripheral nerves [81], and by the mechanism of active transport within the neurons, more specifically through the motor proteins kinesin and dynein [69], and via microtubules, travel in a retrograde way and reach the CNS [82]. These neurons could be motor, sensory or autonomic neurons, but are most often olfactory neurons [69, 81, 83].

There is growing evidence that CoVs may initially infect peripheral nerve endings and then enter the CNS through a synapse-connected route [84-86]. This trans-synaptic transmission has been well documented for some CoVs, such as HEV67 [84, 85, 87, 88]. There is also data supporting the notion that $\mathrm{HCoV}-\mathrm{OC} 43$ might also penetrate the CNS through cranial peripheral nerves [40], as occurs with other respiratory viruses [respiratory syncytial virus (RSV) and influenza virus] [81]. Dubé et.al (2018) showed that viral particles could be passively released/diffused or transported via axonal transport (neuron-toneuron) by axoplasmic flow in cell cultures [40]. It also appears that neurons are very sensitive to SARS-CoV infection, due to their host cell receptors [39]. More specifically, the S1 unit of the S protein of the virus binds to ACE2 receptor of the neuron and with the action of the serine protease transmembrane protease, serine 2 (TMPRSS2) activates the S protein, that allows the virus to invade the neuron [89]. 
neuroepithelium and starts neuropropagation at the olfactory bulbs [40, 92, 93]. It has been reported that 3 days after nasal inoculation in mice, viral antigens of $\mathrm{HCoV}-\mathrm{OC} 43$ can be found in the olfactory bulb [both in the olfactory sensory neurons (OSN) and in dendrites-associated cilia [40]] while no virus is found in perivascular blood cells or other CNS sites [93]. The virus then has the ability to reach highly susceptible regions of the cortex, the mesolimbic cortex or other areas associated with olfaction [40], such as the hippocampus and the amygdala, and finally through trans-neuronal propagation, it may reach the brainstem and the spinal cord [94]. The virus can be detected in the entirety of the brain just 7 days after the nasal inoculation, suggesting a relatively rapid dissemination once it invades the CNS, leading to acute encephalitis and death [93]. Moreover, ablation of the olfactory bulb after nasal infection of MHV blocked the spread [95], strongly supporting the olfactory pathway dissemination theory. SARS-CoV, which is homologous to SARSCoV-2, was also detected in the CNS of susceptible mice after intranasal infection, showing its neuroinvasive capabilities $[39,73]$. More specifically, Netland et al. (2008) detected SARS-CoV in the olfactory bulb of mice approximately 3 days after nasal inhalation, and in the mesolimbic cortex only 1 day later, in addition to other brain regions and the brainstem, invading almost the entirety of the brain [39].

\section{Other neuronal routes}

SARS-CoV-2 might also be transferred to the CNS through the trigeminal nerve, which innervates nociceptive cells in the nasal cavity, and has been successfully tested for drug transportation $[96,97]$. Sensory nerve endings of the trigeminal nerve also exist in the conjunctiva, where SARS-CoV-2 RNA fragments have been found in a patient with conjunctivitis [98], and in the taste buds, ascending not only in trigeminal nuclei, but also to the nuclei of the solitary tract [59].

It has been demonstrated that some viruses, such as influenza, can enter the CNS via the sensory fiber of the vagus nerve in the respiratory tract [81, 86, 99101]. This also represents another communication route between the emesis center, the vagus nerve and the GI tract, which may play a role in this retrograde penetration of the SARS-CoV-2 to the CNS [59]. In addition, local peripheral nerves from the GI system might be infected, as SARS-CoV-2 also infects the GI tract [61-63]. As noted above, many researchers have demonstrated that the brain stem is an area that is particularly infected by SARS-CoV [39, 73] and MERS-CoV [91]; this adds support to the notion that through trans-synaptic transmission, SARS-CoV-2 might also infect the brainstem from the respiratory system [52]. However, no direct proof that SARS-CoV-2 and HCoVs use the vagus nerve for neuroinvasive purposes has been published [59].

\section{The neurogenic hypothesis}

It is worth mentioning that dyspnea may stem from the primary CNS infection, mainly through the olfactory mechanism that leads to the brainstem, where the stem nuclei and the solitary tract are connected to the respiratory system [52, 102]. Netland et al. (2008) demonstrated that the main gate of SARS-CoV infection in mice was the olfactory pathway and could lead to death. However, the presence of the virus in lungs was low suggesting that infected neurons in 
the medulla and the cardiorespiratory center were responsible for this outcome [39]. This scenario proposes that direct infection of the CNS might be the primary gate of the virus in the organism [39, 52]. Additionally, postmortem examination of SARS-CoV patients detected viral particles in the brain almost exclusively in neurons, rather than in glia [34-36], adding more support to the neuronal rather than the hematogenous pathway.

\section{Lymphatic tissue and CSF}

A recent study found that the genes for ACE2 receptors and TMPRSS2, responsible for the binding of SARS-CoV-2, are expressed in the olfactory epithelial support and stem cells, but not in the olfactory sensory neurons (OSN) of mice and humans [103]. It has also been demonstrated that nasal inoculation of HCoV-229E to human volunteers disrupted the nasal epithelium, damaging and decreasing the number of the ciliated cells [104]. Perineural spaces of olfactory nerves and the nasal lymphatic tissue are important for drainage of the $\mathrm{CSF}$, as they communicate with the CSF through channels made by the ensheathing cells $[105,106]$. That means that the nasal olfactory epithelium and its lymphatic tissue may contribute to SARS-CoV-2 neuroinvasion in another indirect pathway.

Lymphatic endothelial cells express receptors of CD209L, another receptor for SARS-CoVs, with lower affinity than ACE2 that is expressed mainly in lymphatic and liver tissues [107, 108]. It has been described that human hilar and mesenteric lymph nodes can be invaded by SARS-CoV [109, 110]. It is not unreasonable to hypothesize that other lymphatic networks, like those in oral tissues [111] or in the ocular mucosa [112] could be targets for SARS-CoV-2. Following this train of thought, the case of a patient presenting with seizures and SARS-CoV-2 in the CSF, 10 days after conjunctivitis [49], demonstrates possible neuroinvasion through the conjunctiva. According to this theory, viremia could be the sequela of infection of lymphatic tissue in the affected organ, such as the respiratory or GI tract $[18,59]$, leading to the neuroinvasion via the aforementioned hematogenous route.

The CNS microenvironment following SARS-CoV-2 infection is presented at Fig. 3 [Fig. 3].

\section{Conclusions}

In an attempt to understand the possible mechanisms of SARS-CoV-2 neuroinvasion, it is reasonable to study the neuroinvasive behavior of known CoVs that have been studied for a longer period of time. The two basic common pathways for viral neuroinvasion that have been better described so far are hematogenous and neuronal. It has been demonstrated that coronaviruses can use either pathway to achieve CNS penetration. SARS-CoV-2 seems to not be an exception, as it shares common features with the other coronaviruses and can induce neurological symptoms. There are indications that SARS-CoV-2 can take advantage of both the hematogenous and neuronal routes, as it principally uses the ACE2 receptor that exists in circulatory and nervous systems. In addition, SARS-CoV-2 may also penetrate lymphatic tissues leading to entrance to the CNS. 


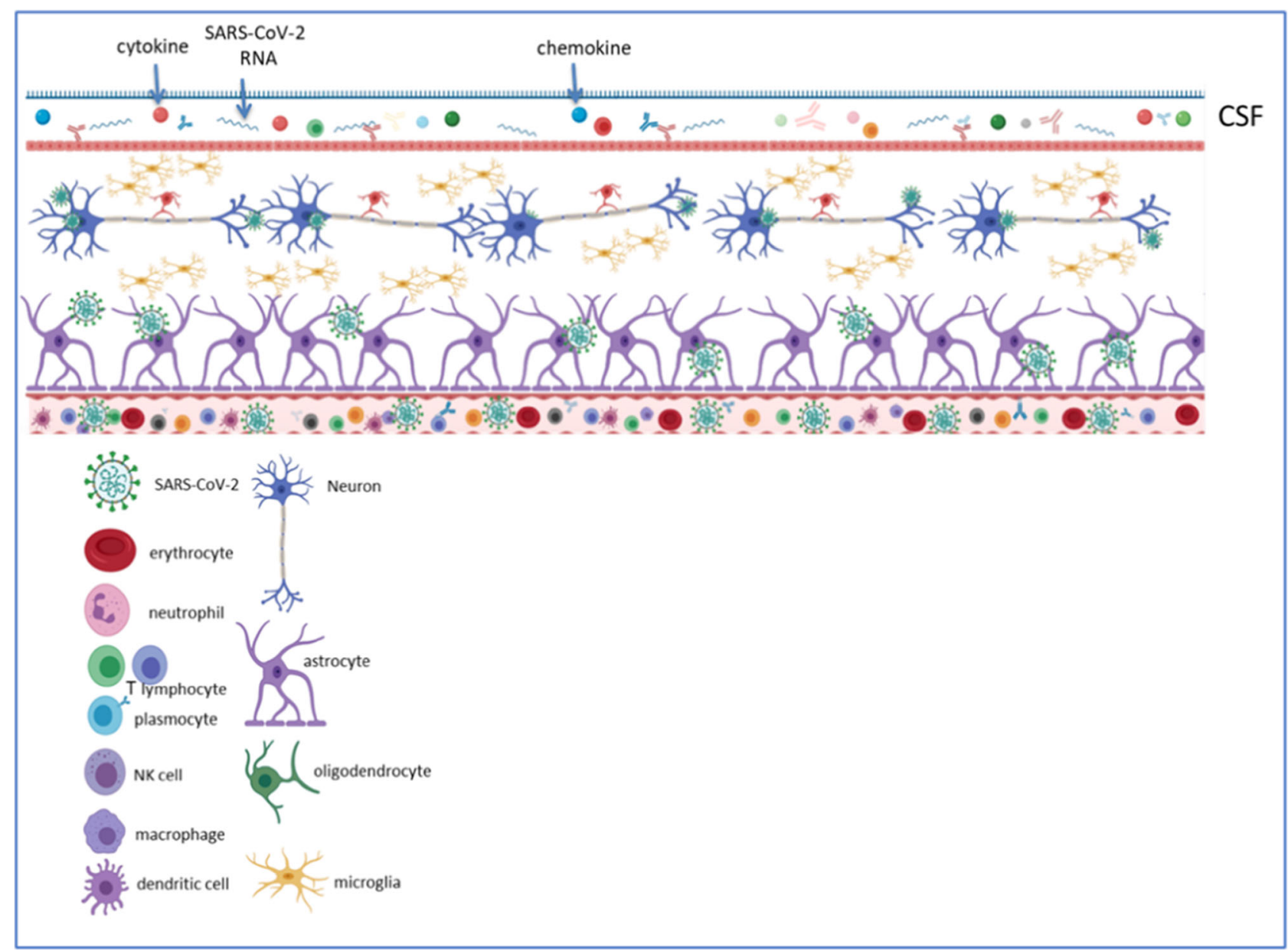

Fig. 3. The CNS microenvironment following SARS-CoV-2 infection. Spread of SARS-CoV-2 from lungs to the CNS can most likely be achieved through the haematogenous route. In addition, it can enter the CNS through the olfactory bulb, and once the infectious agent persists due to the inability of the immune system to control/suppress viral replication, the virus may reach the whole brain and the CSF, and participate in demyelination. In the hematogenous route, SARS-CoV-2 may gain access by infecting endothelial cells of the blood-brain-barrier, epithelial cells of the blood-cerebrospinal fluid barrier in the choroid plexus, or it may indeed use inflammatory cells as "Trojan horse" to obtain access into the CNS. Experimental data suggest that primary glial cultures can secrete a series of inflammatory cytokines participating in the perpetuation of viral infection and further inflicting CNS tissue damage. The role of astrocytes in the machinery of SARS-CoV-2 mediated CNS pathology is yet undetermined and remains to be defined.

Based on the data presented in this review, the CNS may be affected by a subsequent effect of a primary systemic infection, through hematogenous or neuronal pathways. However, the CNS may also be the primary entry organ, infected mainly through the olfactory route, via which the virus enters the boby and spreads to other systems. In that case, the aforementioned "neurogenic hypothesis" is reinforced, and this invasion route could be particularly dangerous, as it could lead to the infection of the brainstem and the respiratory center, causing respiratory failure. More research is needed to confirm these hypotheses and will lead to more efficient therapeutic and preventive strategies. 


\section{Compliance with Ethical Standards}

\section{Conflict of Interest}

The authors declare that they have no conflict of interest.

\section{References and Recommended Reading}

Papers of particular interest, published recently, have been

highlighted as:

- Of importance

1. Vabret A, Dina J, Brison E, Brouard J, Freymuth F. Human Coronaviruses. Pathol Biol (Paris). 2009;57(2):149-60. https://doi.org/10.1016/j.patbio. 2008.02.018.

2. Nitulescu GM, Paunescu H, Moschos SA, Petrakis D, Nitulescu G, Ion GND, et al. Comprehensive analysis of drugs to treat Sars-Cov-2 infection: mechanistic insights into current Covid-19 therapies (review). Int J Mol Med. 2020;46(2):467-88. https://doi.org/10. 3892/ijmm.2020.4608.

3. Tsatsakis A, Petrakis D, Nikolouzakis TK, Docea AO, Calina D, Vinceti M, et al. Covid-19, an opportunity to reevaluate the correlation between long-term effects of anthropogenic pollutants on viral epidemic/pandemic events and prevalence. Food Chem Toxicol.

2020;141:111418. https://doi.org/10.1016/j.fct.2020. 111418

4. Chan JF, Lau SK, To KK, Cheng VC, Woo PC, Yuen KY. Middle East respiratory syndrome coronavirus: another zoonotic Betacoronavirus causing Sars-like disease. Clin Microbiol Rev. 2015;28(2):465-522. https://doi. org/10.1128/cmr.00102-14.

5. Calina D, Docea AO, Petrakis D, Egorov AM, Ishmukhametov AA, Gabibov AG, et al. Towards effective Covid-19 vaccines: updates, perspectives and challenges (review). Int J Mol Med. 2020;46(1):3-16. https://doi.org/10.3892/ijmm.2020.4596.

6. Petrakis D, Margină D, Tsarouhas K, Tekos F, Stan M, Nikitovic D, et al. Obesity - a risk factor for increased Covid-19 prevalence, severity and lethality (review). Mol Med Rep. 2020;22(1):9-19. https://doi.org/10. 3892/mmr.2020.11127.

7. Paules CI, Marston HD, Fauci AS. Coronavirus infectionsmore than just the common cold. Jama. 2020;323:707-8. https://doi.org/10.1001/jama.2020.0757.

8. Corman VM, Muth D, Niemeyer D, Drosten C. Hosts and sources of endemic human coronaviruses. Adv Virus Res. 2018;100:163-88. https://doi.org/10.1016/ bs.aivir.2018.01.001.

9. Kin N, Miszczak F, Lin W, Gouilh MA, Vabret A. Genomic analysis of 15 human coronaviruses Oc43 (Hcov-Oc43s) circulating in France from 2001 to 2013 reveals a high intra-specific diversity with new recombinant genotypes. Viruses. 2015;7(5):2358-77. https:// doi.org/10.3390/v7052358.
10. Farsalinos $\mathrm{K}$, Niaura R, Le Houezec J, Barbouni A, Tsatsakis A, Kouretas D, et al. Editorial: nicotine and Sars-Cov-2: Covid-19 may be a disease of the nicotinic cholinergic system. Toxicol Rep. 2020;7:658-63. https://doi.org/10.1016/j.toxrep. 2020.04 .012$.

11. Goumenou M, Sarigiannis D, Tsatsakis A, Anesti O, Docea AO, Petrakis D, et al. Covid-19 in northern Italy: an integrative overview of factors possibly influencing the sharp increase of the outbreak (review). Mol Med Rep. 2020;22(1):2032. https://doi.org/10.3892/mmr.2020.11079.

12. Goumenou M, Spandidos DA, Tsatsakis A. [editorial] possibility of transmission through dogs being a contributing factor to the extreme Covid-19 outbreak in North Italy. Mol Med Rep. 2020;21(6):2293-5. https://doi.org/10.3892/mmr.2020.11037.

13. Docea AO, Tsatsakis A, Albulescu D, Cristea O, Zlatian O, Vinceti $M$, et al. A new threat from an old enemy: reemergence of coronavirus (review). Int J Mol Med. 2020;45(6):1631-43. https://doi.org/10.3892/ijmm. 2020.4555.

14. $\quad$ Lu R, Zhao X, Li J, Niu P, Yang B, Wu H, et al. Genomic Characterisation and Epidemiology of 2019 Novel Coronavirus: Implications for Virus Origins and Receptor Binding. Lancet. 2020;395(10224):565-74. https://doi.org/10.1016/S0140-6736(20)30251-8 Describes the genomic characteristics of SARS-CoV-2, by genome sequences of samlpes from some of the first covid-19 patients from Huanan seafood market in Wuhan, and compares it to other coronaviruses. Phylogenetic analysis of SARS$\mathrm{CoV}-2$ showed that SARS-CoV-2 belongs to the subgenus of Sarbecovirus of the genus Betacoronavirus, with its closest relatives being two bat-coronaviruses, suggesting bats as the original host of the virus. Moreover, revealed that its receptorbinding domain structure is similar to that of SARS-CoV, indicating, after structural analysis, ACE-2 in humans as a possible binding receptor.

15. Rabaan AA, Al-Ahmed SH, Haque S, Sah R, Tiwari R, Malik YS, et al. Sars-Cov-2, Sars-Cov, and Mers-Cov: a comparative overview. Infez Med. 2020;28(2):174-84.

16. Zhu N, Zhang D, Wang W, Li X, Yang B, Song J, et al. A novel coronavirus from patients with pneumonia in China, 2019. N Engl J Med. 2020;382(8):727-33. https://doi.org/10.1056/NEJMoa2001017. 
17. Giraudon P, Bernard A. Inflammation in Neuroviral diseases. J Neural Transm (Vienna). 2010;117(8):899906. https://doi.org/10.1007/s00702-010-0402-y.

18. Desforges M, Le Coupanec A, Dubeau P, Bourgouin A, Lajoie L, Dubé M, et al. Human Coronaviruses and Other Respiratory Viruses: Underestimated Opportunistic Pathogens of the Central Nervous System? Viruses. 2019;12(1):14. https://doi.org/10.3390/ v12010014.

19. Arbour N, Day R, Newcombe J, Talbot PJ. Neuroinvasion by human respiratory coronaviruses. J Virol. 2000;74(19):8913-21. https://doi.org/10.1128/jvi.74. 19.8913-8921.2000.

20. Perlman S, Netland J. Coronaviruses post-Sars: update on replication and pathogenesis. Nat Rev Microbiol. 2009;7(6):439-50. https://doi.org/10.1038/ nrmicro2147.

21. Lau KK, Yu WC, Chu CM, Lau ST, Sheng B, Yuen KY. Possible central nervous system infection by Sars coronavirus. Emerg Infect Dis. 2004;10(2):342-4. https://doi.org/10.3201/eid1002.030638.

22. Montalvan V, Lee J, Bueso T, De Toledo J, Rivas K. Neurological manifestations of Covid-19 and other coronavirus infections: a systematic review. Clin Neurol Neurosurg. 2020;194:105921. https://doi.org/10. 1016/j.clineuro.2020.105921.

23. Bergmann CC, Lane TE, Stohlman SA. Coronavirus infection of the central nervous system: host-virus stand-off. Nat Rev Microbiol. 2006;4(2):121-32. https://doi.org/10.1038/nrmicro1343.

24. Glass WG, Subbarao K, Murphy B, Murphy PM. Mechanisms of host defense following severe acute respiratory syndrome-coronavirus (Sars-Cov) pulmonary infection of mice. J Immunol. 2004;173(6):40309. https://doi.org/10.4049/jimmunol.173.6.4030.

25. Bonavia A, Arbour N, Yong VW, Talbot PJ. Infection of primary cultures of human neural cells by human coronaviruses 229e and Oc43. J Virol.

1997;71(1):800-6.

26. Mentis AA, Dardiotis E, Grigoriadis N, Petinaki E, Hadjigeorgiou GM. Viruses and multiple sclerosis: from mechanisms and pathways to translational research opportunities. Mol Neurobiol.

2017;54(5):3911-23. https://doi.org/10.1007/ s12035-017-0530-6.

27. Mentis AA, Dardiotis E, Grigoriadis N, Petinaki E, Hadjigeorgiou GM. Viruses and endogenous retroviruses in multiple sclerosis: from correlation to causation. Acta Neurol Scand. 2017;136(6):606-16. https:// doi.org/10.1111/ane.12775.

28. Burks JS, DeVald BL, Jankovsky LD, Gerdes JC. Two coronaviruses isolated from central nervous system tissue of two multiple sclerosis patients. Science. 1980;209(4459):933-4. https://doi.org/10.1126/ science.7403860.

29. Bleau C, Filliol A, Samson M, Lamontagne L. Brain invasion by mouse hepatitis virus depends on impairment of tight junctions and Beta interferon production in brain microvascular endothelial cells. J Virol.
2015;89(19):9896-908. https://doi.org/10.1128/jvi. 01501-15.

30. Saad M, Omrani AS, Baig K, Bahloul A, Elzein F, Matin $\mathrm{MA}$, et al. Clinical aspects and outcomes of 70 patients with Middle East respiratory syndrome coronavirus infection: a single-center experience in Saudi Arabia. Int J Infect Dis. 2014;29:301-6. https://doi.org/10.1016/j. ijid.2014.09.003.

31. Kim JE, Heo JH, Kim HO, Song SH, Park SS, Park TH, et al. Neurological complications during treatment of Middle East respiratory syndrome. J Clin Neurol. 2017;13(3):227-33. https://doi.org/10.3988/jcn. 2017.13.3.227.

32. Hung EC, Chim SS, Chan PK, Tong YK, Ng EK, Chiu $\mathrm{RW}$, et al. Detection of Sars coronavirus Rna in the cerebrospinal fluid of a patient with severe acute respiratory syndrome. Clin Chem. 2003;49(12):2108-9. https://doi.org/10.1373/clinchem.2003.025437.

33. Yeh EA, Collins A, Cohen ME, Duffner PK, Faden H. Detection of coronavirus in the central nervous system of a child with acute disseminated encephalomyelitis. Pediatrics. 2004;113(1 Pt 1):e73-6. https://doi.org/10. 1542/peds.113.1.e73.

34. Ding Y, He L, Zhang Q, Huang Z, Che X, Hou J, et al. Organ distribution of severe acute respiratory syndrome (Sars) associated coronavirus (Sars-Cov) in Sars patients: implications for pathogenesis and virus transmission pathways. J Pathol. 2004;203(2):622-30. https://doi.org/10.1002/path.1560.

35. Gu J, Gong E, Zhang B, Zheng J, Gao Z, Zhong Y, et al. Multiple organ infection and the pathogenesis of Sars. J Exp Med. 2005;202(3):415-24. https://doi.org/10. 1084/jem.20050828.

36. Xu J, Zhong S, Liu J, Li L, Li Y, Wu X, et al. Detection of severe acute respiratory syndrome coronavirus in the brain: potential role of the chemokine Mig in pathogenesis. Clin Infect Dis. 2005;41(8):1089-96. https:// doi.org/10.1086/444461.

37. Cameron MJ, Ran L, Xu L, Danesh A, BermejoMartin JF, Cameron CM, et al. Interferonmediated Immunopathological events are associated with atypical innate and adaptive immune responses in patients with severe acute respiratory syndrome. J Virol. 2007;81(16):8692-706. https:// doi.org/10.1128/jvi.00527-07.

38. Zhang QL, Ding YQ, Hou JL, He L, Huang ZX, Wang $\mathrm{HJ}$, et al. Detection of severe acute respiratory syndrome (Sars)-associated coronavirus Rna in autopsy tissues with in situ hybridization. Di Yi Jun Yi Da Xue Xue Bao. 2003;23(11):1125-7.

39. Netland J, Meyerholz DK, Moore S, Cassell M, Perlman S. Severe acute respiratory syndrome coronavirus infection causes neuronal death in the absence of encephalitis in mice transgenic for human Ace2. J Virol. 2008;82(15):7264-75. https://doi.org/10.1128/jvi. 00737-08.

40. Dubé M, Le Coupanec A, Wong AHM, Rini JM, Desforges M, Talbot PJ. Axonal Transport Enables Neuronto-Neuron Propagation of Human Coronavirus Oc43. 
J Virol. 2018;92(17):e00404-18. https://doi.org/10. 1128/jvi.00404-18.

41. Boziki MK, Mentis AA, Shumilina M, Makshakov G, Evdoshenko E, Grigoriadis N. Covid-19 Immunopathology and the Central Nervous System: Implication for Multiple Sclerosis and Other Autoimmune Diseases with Associated Demyelination. Brain Sci. 2020;10(6):345. https://doi.org/10.3390/ brainsci10060345.

42.• Mao L, Jin H, Wang M, Hu Y, Chen S, He Q, et al. Neurologic Manifestations of Hospitalized Patients with Coronavirus Disease 2019 in Wuhan, China. JAMA Neurol. 2020. https://doi.org/10.1001/ jamaneurol.2020.1127

One of the first reviews that reported neurological manifestations in Covid-19 patients, in retrospective, oservational case series, of the Union Hospital of Huazhong University of Science and Technology in Wuhan, China, demonstrating their high frequency.

43. Chen ZM, Fu JF, Shu Q, Chen YH, Hua CZ, Li FB, Lin R, Tang LF, Wang TL, Wang W, Wang YS, $\mathrm{Xu}$ WZ, Yang ZH, Ye S, Yuan TM, Zhang CM, Zhang YY Diagnosis and Treatment Recommendations for Pediatric Respiratory Infection Caused by the 2019 Novel Coronavirus. World J Pediatr 2020:1-7. doi:https://doi.org/10.1007/s12519020-00345-5.

44. Chen N, Zhou M, Dong X, Qu J, Gong F, Han Y, et al. Epidemiological and clinical characteristics of 99 cases of 2019 novel coronavirus pneumonia in Wuhan, China: A Descriptive Study. Lancet. 2020;395(10223):507-13.

45. Wu Y, Xu X, Chen Z, Duan J, Hashimoto K, Yang L, et al. Nervous system involvement after infection with Covid-19 and other coronaviruses. Brain Behav Immun. 2020;87:18-22. https://doi.org/10.1016/j. bbi.2020.03.031.

46. Huang C, Wang Y, Li X, Ren L, Zhao J, Hu Y, et al. Clinical features of patients infected with 2019 novel coronavirus in Wuhan, China. Lancet. 2020;395(10223):497-506. https://doi.org/10.1016/ s0140-6736(20)30183-5

Reports the clinical, epidemiological, laboratory, and radiological features and clinical and treatment outcomes of the first covid-19 pneumonia cases in Wuhan, China.

47. Poyiadji N, Shahin G, Noujaim D, Stone M, Patel S, Griffith B. Covid-19-associated acute hemorrhagic necrotizing encephalopathy: Ct and Mri features. Radiology. 2020;201187:E119-20. https://doi.org/10. 1148/radiol.2020201187.

48. Moriguchi T, Harii N, Goto J, Harada D, Sugawara H, Takamino J, et al. A First Case of Meningitis/ Encephalitis Associated with Sars-Coronavirus-2, Int J Infect Dis. 2020;94:55-8. https://doi.org/10.1016/j. ijid.2020.03.062

Reports one of the first case of meningitis associated with SARS$\mathrm{CoV}-2$ infection, detecting SARS-CoV-2 RNA in CSF, but not in the nasopharyngeal swab, and accompanied by MRI findings of meningitis.
49. Fasano A, Cavallieri F, Canali E, Valzania F. First motor seizure as presenting symptom of Sars-Cov-2 infection. Neurol Sci. 2020;41:1651-3. https://doi.org/10.1007/ s10072-020-04460-z.

50. Paniz-Mondolfi A, Bryce C, Grimes Z, Gordon RE, Reidy J, Lednicky J, et al. Central Nervous System Involvement by Severe Acute Respiratory Syndrome Coronavirus -2 (Sars-Cov-2). J Med Virol. 2020. https://doi.org/10.1002/jmv.25915

Reports the presence of SARS-CoV-2 in neural and capillary endothelial cells in brain tissue from postmortem examinations of a covid-19 patient, providing evidenve of its neuroinvasive and neurotropic capabillities.

51. Nath A. Neurologic complications of coronavirus infections. Neurology. 2020;94:809-10. https://doi. org/10.1212/wnl.0000000000009455.

52. Li YC, Bai WZ, Hashikawa T. The Neuroinvasive potential of Sars-Cov2 may play a role in the respiratory failure of Covid-19 patients. J Med Virol. 2020;92:5525. https://doi.org/10.1002/jmv.25728.

53. Wan Y, Shang J, Graham R, Baric RS, Li F. Receptor Recognition by the Novel Coronavirus from Wuhan: An Analysis Based on Decade-Long Structural Studies of Sars Coronavirus. J Virol. 2020;94(7). doi:https:// doi.org/10.1128/jvi.00127-20.

54. Wrapp D, Wang N, Corbett KS, Goldsmith JA, Hsieh CL, Abiona O, et al. Cryo-Em structure of the 2019Ncov spike in the Prefusion conformation. Science. 2020;367(6483):1260-3. https://doi.org/10.1126/ science.abb2507.

55. Hamming I, Timens W, Bulthuis ML, Lely AT, Navis G, van Goor $H$. Tissue distribution of Ace 2 protein, the functional receptor for Sars coronavirus. A first step in understanding Sars pathogenesis. J Pathol. 2004;203(2):631-7. https://doi.org/10.1002/path. 1570.

56. Qi F, Qian S, Zhang S, Zhang Z. Single cell Rna sequencing of 13 human tissues identify cell types and receptors of human coronaviruses. Biochem Biophys Res Commun. 2020;526:135-40.

57. Li W, Moore MJ, Vasilieva N, Sui J, Wong SK, Berne MA, et al. Angiotensin-converting enzyme 2 is a functional receptor for the Sars coronavirus. Nature. 2003;426(6965):450-4. https://doi.org/10.1038/ nature02145.

58. Qian Z, Travanty EA, Oko L, Edeen K, Berglund A, Wang J, et al. Innate immune response of human alveolar type ii cells infected with severe acute respiratory syndromecoronavirus. Am J Respir Cell Mol Biol. 2013;48(6):7428. https://doi.org/10.1165/rcmb.2012-0339OC.

59. Li Z, Liu T, Yang N, Han D, Mi X, Li Y, et al. Neurological manifestations of patients with Covid-19: potential routes of Sars-Cov-2 Neuroinvasion from the periphery to the brain. Front Med. 2020;4:1-9. https:// doi.org/10.1007/s11684-020-0786-5.

60. Gonzalez-Scarano F, Tyler KL. Molecular pathogenesis of neurotropic viral infections. Ann Neurol. 1987;22(5):565-74. https://doi.org/10.1002/ana. 410220502 . 
61. Chen H, Guo J, Wang C, Luo F, Yu X, Zhang W, et al. Clinical characteristics and intrauterine vertical transmission potential of Covid-19 infection in nine pregnant women: a retrospective review of medical records. Lancet. 2020;395(10226):809-15.

62. Jiang F, Deng L, Zhang L, Cai Y, Cheung CW, Xia Z. Review of the Clinical Characteristics of Coronavirus Disease 2019 (Covid-19). J Gen Intern Med. 2020:1-5.

63. Xiao F, Tang M, Zheng X, Liu Y, Li X, Shan H. Evidence for Gastrointestinal Infection of Sars-Cov-2. Gastroenterology. 2020;158(6):1831-3 e3.

64. Koyuncu OO, Hogue IB, Enquist LW. Virus infections in the nervous system. Cell Host Microbe.

2013;13(4):379-93. https://doi.org/10.1016/j.chom. 2013.03.010.

65. Suen WW, Prow NA, Hall RA, Bielefeldt-Ohmann H. Mechanism of West Nile virus Neuroinvasion: a critical appraisal. Viruses. 2014;6(7):2796-825. https://doi. org/10.3390/v6072796.

66. Cowley TJ, Weiss SR. Murine coronavirus Neuropathogenesis: determinants of virulence. J Neuro-Oncol. 2010;16(6):427-34. https://doi.org/10.3109/ 13550284.2010 .529238$.

67. Cabirac GF, Soike KF, Butunoi C, Hoel K, Johnson S, Cai GY, et al. Coronavirus Jhm Omp1 pathogenesis in owl monkey Cns and coronavirus infection of owl monkey Cns via peripheral routes. Adv Exp Med Biol. 1993;342:347-52. https://doi.org/10.1007/978-14615-2996-5_53.

68. Hocke AC, Becher A, Knepper J, Peter A, Holland G, Tönnies $M$, et al. Emerging human Middle East respiratory syndrome coronavirus causes widespread infection and alveolar damage in human lungs. Am J Respir Crit Care Med. 2013;188(7):882-6. https://doi.org/10. 1164/rccm.201305-0954LE.

69. Swanson PA 2nd, McGavern DB. Viral diseases of the central nervous system. Curr Opin Virol. 2015;11:4454. https://doi.org/10.1016/j.coviro.2014.12.009.

70. Roe K, Kumar M, Lum S, Orillo B, Nerurkar VR, Verma $\mathrm{S}$. West Nile virus-induced disruption of the bloodbrain barrier in mice is characterized by the degradation of the Junctional complex proteins and increase in multiple matrix Metalloproteinases. J Gen Virol. 2012;93(Pt 6):1193-203. https://doi.org/10.1099/vir. 0.040899-0.

71. Honigsbaum M. "an inexpressible dread": psychoses of influenza at fin-De-Siècle. Lancet.

2013;381(9871):988-9. https://doi.org/10.1016/ s0140-6736(13)60701-1.

72. Wohleb ES, McKim DB, Sheridan JF, Godbout JP. Monocyte trafficking to the brain with stress and inflammation: a novel Axis of immune-to-brain communication that influences mood and behavior. Front Neurosci. 2014;8:447. https://doi.org/10.3389/fnins.2014.00447.

73. McCray PB Jr, Pewe L, Wohlford-Lenane C, Hickey M, Manzel L, Shi L, et al. Lethal infection of K18-Hace2 mice infected with severe acute respiratory syndrome coronavirus. J Virol. 2007;81(2):813-21. https://doi. org/10.1128/jvi.02012-06.
74. McGavern DB, Kang SS. Illuminating viral infections in the nervous system. Nat Rev Immunol.

2011;11(5):318-29. https://doi.org/10.1038/nri2971.

75. Dahm T, Rudolph H, Schwerk C, Schroten H, Tenenbaum $\mathrm{T}$. Neuroinvasion and inflammation in viral central nervous system infections. Mediat Inflamm. 2016;2016:8562805-16. https://doi.org/10.1155/ $2016 / 8562805$.

76. Desforges M, Miletti TC, Gagnon M, Talbot PJ. Activation of human monocytes after infection by human coronavirus 229e. Virus Res. 2007;130(1-2):228-40. https://doi.org/10.1016/j.virusres.2007.06.016.

77. Collins AR. In vitro detection of apoptosis in monocytes/macrophages infected with human coronavirus. Clin Diagn Lab Immunol. 2002;9(6):1392-5. https://doi.org/10.1128/cdli.9.6.1392-1395.2002.

78. Mesel-Lemoine M, Millet J, Vidalain PO, Law H, Vabret A, Lorin $\mathrm{V}$, et al. A human coronavirus responsible for the common cold massively kills dendritic cells but not monocytes. J Virol. 2012;86(14):7577-87. https://doi. org/10.1128/jvi.00269-12.

79. Wentworth DE, Tresnan DB, Turner BC, Lerman IR, Bullis B, Hemmila EM, et al. Cells of human Aminopeptidase $\mathrm{N}(\mathrm{Cd} 13)$ transgenic mice are infected by human coronavirus-229e in vitro, but not in vivo. Virology. 2005;335(2):185-97. https://doi.org/10.1016/ j.virol.2005.02.023.

80. Kontoyiannis DP, Pasqualini R, Arap W. Aminopeptidase $\mathrm{N}$ inhibitors and Sars. Lancet. 2003;361(9368):1558. https://doi.org/10.1016/ s0140-6736(03)13186-8.

81. Bohmwald K, Gálvez NMS, Ríos M, Kalergis AM. Neurologic alterations due to respiratory virus infections. Front Cell Neurosci. 2018;12:386. https://doi.org/10. 3389/fncel.2018.00386.

82. Berth SH, Leopold PL, Morfini GN. Virus-Induced Neuronal Dysfunction and Degeneration. Front Biosci (Landmark Ed). 2009;14:5239-59. https://doi.org/10. 2741/3595.

83. Desforges M, Le Coupanec A, Stodola JK, MeessenPinard M, Talbot PJ. Human coronaviruses: viral and cellular factors involved in Neuroinvasiveness and Neuropathogenesis. Virus Res. 2014;194:145-58. https://doi.org/10.1016/j.virusres.2014.09.011.

84. Li Y-C, Bai W-Z, Hirano N, Hayashida T, Hashikawa T. Coronavirus infection of rat dorsal root ganglia: Ultrastructural characterization of viral replication, transfer, and the early response of satellite cells. Virus Res. 2012;163(2):628-35.

85. Li YC, Bai WZ, Hirano N, Hayashida T, Taniguchi T, Sugita $Y$, et al. Neurotropic virus tracing suggests a membranous-coating-mediated mechanism for Transsynaptic communication. J Comp Neurol.

2013;521(1):203-12.

86. Matsuda K, Park CH, Sunden Y, Kimura T, Ochiai K, $\mathrm{Kida} \mathrm{H}$, et al. The Vagus nerve is one route of Transneural invasion for Intranasally inoculated influenza a virus in mice. Vet Pathol. 2004;41(2):101-7. https:// doi.org/10.1354/vp.41-2-101. 
87. Mengeling WL, Boothe AD, Ritchie AE. Characteristics of a coronavirus (strain $67 \mathrm{n}$ ) of pigs. Am J Vet Res. 1972;33(2):297-308.

88. Andries K, Pensaert MB. Immunofluorescence studies on the pathogenesis of Hemagglutinating encephalomyelitis virus infection in pigs after Oronasal inoculation. Am J Vet Res. 1980;41(9):1372-8.

89. Hoffmann M, Kleine-Weber H, Schroeder S, Krüger N, Herrler T, Erichsen S, et al. Sars-Cov-2 Cell Entry Depends on Ace 2 and Tmprss 2 and Is Blocked by a Clinically Proven Protease Inhibitor. Cell. 2020;181(2):271-80. e8. https://doi.org/10.1016/j. cell.2020.02.052.

90. Ryzhikov AB, Goncharova EP, Bulychev LE, Sergeev AN, Dmitriev IP, Pliasunov IV, et al. Studying the Possibility of Respiratory Immunization against TickBorne Encephalitis. Vestn Ross Akad Med Nauk. 1998;1998(4):17-20.

91. Li K, Wohlford-Lenane C, Perlman S, Zhao J, Jewell AK, Reznikov LR, et al. Middle East respiratory syndrome coronavirus causes multiple organ damage and lethal disease in mice transgenic for human Dipeptidyl peptidase 4. J Infect Dis. 2016;213(5):712-22. https://doi. org/10.1093/infdis/jiv499.

92. Jacomy $\mathrm{H}$, Talbot PJ. Vacuolating encephalitis in mice infected by human coronavirus Oc43. Virology. 2003;315(1):20-33. https://doi.org/10.1016/s00426822(03)00323-4.

93. St-Jean JR, Jacomy H, Desforges M, Vabret A, Freymuth F, Talbot PJ. Human respiratory coronavirus Oc43: genetic stability and Neuroinvasion. J Virol. 2004;78(16):8824-34. https://doi.org/10.1128/jvi.78. 16.8824-8834.2004.

94. Desforges M, Favreau DJ, Brison É, Desjardins J, Meessen-Pinard M, Jacomy H et al. Human Coronaviruses: Respiratory Pathogens Revisited as Infectious Neuroinvasive, Neurotropic, and Neurovirulent Agents. 2013.

95. Perlman S, Jacobsen G, Afifi A. Spread of a neurotropic murine coronavirus into the Cns via the trigeminal and olfactory nerves. Virology. 1989;170(2):556-60. https://doi.org/10.1016/0042-6822(89)90446-7.

96. Lochhead JJ, Kellohen KL, Ronaldson PT, Davis TP. Distribution of insulin in trigeminal nerve and brain after intranasal administration. Sci Rep. 2019;9(1):2621. https://doi.org/10.1038/s41598-01939191-5.

97. Lochhead JJ, Thorne RG. Intranasal delivery of biologics to the central nervous system. Adv Drug Deliv Rev. 2012;64(7):614-28. https://doi.org/10.1016/j.addr. 2011.11.002.

98. Sun X, Zhang X, Chen X, Chen L, Deng C, Zou X, et al. The infection evidence of Sars-Cov-2 in ocular surface: a single-center cross-sectional study. MedRxiv. 2020.

99. Hosseini S, Wilk E, Michaelsen-Preusse K, Gerhauser I, Baumgärtner W, Geffers R, et al. Long-term Neuroinflammation induced by influenza a virus infection and the impact on hippocampal neuron morphology and function. J Neurosci. 2018;38(12):3060-80. https:// doi.org/10.1523/jneurosci.1740-17.2018.

100. Driessen AK, Farrell MJ, Mazzone SB, McGovern AE. Multiple neural circuits mediating airway sensations: recent advances in the neurobiology of the urge-tocough. Respir Physiol Neurobiol. 2016;226:115-20. https://doi.org/10.1016/j.resp.2015.09.017.

101. Park CH, Ishinaka M, Takada A, Kida H, Kimura T, Ochiai $\mathrm{K}$, et al. The invasion routes of Neurovirulent a/Hong Kong/483/97 (H5n1) influenza virus into the central nervous system after respiratory infection in mice. Arch Virol. 2002;147(7):1425-36. https://doi. org/10.1007/s00705-001-0750-x.

102. Baig AM, Khaleeq A, Ali U, Syeda H. Evidence of the Covid-19 virus targeting the Cns: tissue distribution, host-virus interaction, and proposed neurotropic mechanisms. ACS Chem Neurosci. 2020;11(7):995-8. https://doi.org/10.1021/ acschemneuro.0c00122.

103. Brann D, Tsukahara T, Weinreb C, Logan DW, Datta SR. Non-Neural Expression of Sars-Cov-2 Entry Genes in the Olfactory Epithelium Suggests Mechanisms Underlying Anosmia in Covid-19 Patients. bioRxiv. 2020.

104. Chilvers M, McKean M, Rutman A, Myint B, Silverman M, O'Callaghan C. The effects of coronavirus on human nasal ciliated respiratory epithelium. Eur Respir J. 2001;18(6):965-70.

105. Dhuria SV, Hanson LR, Frey WH 2nd. Intranasal delivery to the central nervous system: mechanisms and experimental considerations. J Pharm Sci. 2010;99(4):1654-73. https://doi.org/10.1002/jps. 21924.

106. Born J, Lange T, Kern W, McGregor GP, Bickel U, Fehm HL. Sniffing neuropeptides: a Transnasal approach to the human brain. Nat Neurosci. 2002;5(6):514-6. https://doi.org/10.1038/nn849.

107. Li J, Gao J, Xu YP, Zhou TL, Jin YY, Lou JN. Expression of severe acute respiratory syndrome coronavirus receptors, Ace 2 and $\mathrm{Cd} 2091$ in different organ derived microvascular endothelial cells. Zhonghua Yi Xue Za Zhi. 2007;87(12):833-7.

108. Magrone T, Magrone M, Jirillo E. Focus on receptors for coronaviruses with special reference to angiotensin-converting enzyme 2 as a potential drug target - a perspective. Endocr Metab Immune Disord Drug Targets. 2020;20:807-11. https://doi.org/10. 2174/1871530320666200427112902.

109. Zhao JM, Zhou GD, Sun YL, Wang SS, Yang JF, Meng $\mathrm{EH}$, et al. Clinical pathology and pathogenesis of severe acute respiratory syndrome. Zhonghua Shi Yan He Lin Chuang Bing Du Xue Za Zhi. 2003;17(3):21721.

110. Xiao Y, Meng Q, Yin X, Guan Y, Liu Y, Li C, et al. Pathological changes in masked palm civets experimentally infected by severe acute respiratory syndrome (Sars) coronavirus. J Comp Pathol. 2008;138(4):171-9. https://doi.org/10.1016/j.jcpa. 2007.12.005. 
111. Zhang Z, Helman JI, Li LJ. Lymphangiogenesis, lymphatic endothelial cells and lymphatic metastasis in head and neck cancer-a review of mechanisms. Int J Oral Sci. 2010;2(1):5-14.

112. Yucel Y, Gupta N. Lymphatic Drainage from the Eye: A New Target for Therapy. Prog Brain Res. Elsevier. 2015;220:185-98.

\section{Publisher's Note}

Springer Nature remains neutral with regard to jurisdictional claims in published maps and institutional affiliations. 